\title{
Resuscitation of Bacteria after Dechlorination of Treated Drinking Water
}

${ }^{* 1}$ O. O. Adebisi, ${ }^{1}$ Y. I. Kayode, ${ }^{2}$ T. M. Kayode-lsola and ${ }^{1}$ B. A. Saka

${ }^{1}$ Department of Microbiology, University of Ilorin, P.M.B. 1515, llorin, Nigeria

2Department of Biological Science, Adeniran Ogunsanya College of Education, P.M.B. 007, Otto/ljanikin, Lagos, Nigeria

[Corresponding Author: E-mail: soji-olusegun@unilorin.edu.ng; 00.adebisi@outlook.com; P:+234(0)8060510307]

\begin{abstract}
In this study, the effects of initial bacterial load $\left(10^{2}, 10^{4}\right.$ and $10^{6}$ cells $\left./ \mathrm{ml}\right)$ and dechlorination idiosyncrasy on the efficacy of varying concentrations $(0.018-0.126 \% \mathrm{v} / \mathrm{v}$ applied for 30 minutes) of a point-of-use chlorine-based proprietary disinfectant $\left(\right.$ WaterCare $\left.^{\circledR}\right)$ were investigated in drinking water. Results indicated that higher initial cell populations significantly affected the efficacy of the disinfectant. Subsequent dechlorination of the disinfected water resulted in resuscitation of bacteria. This was demonstrated after 1440 minutes post-dechlorination for Salmonella typhi and after at least 120 minutes for Escherichia coli, Proteus vulgaris and Shigella dysenteriae, particularly at lower disinfectant concentrations $(0.018-0.054 \% \mathrm{v} / \mathrm{v})$. Thus, whilst the use of WaterCare ${ }^{\circledR}$ at the recommended dosage $(0.072 \% \mathrm{v} / \mathrm{v}$ or $10 \mathrm{ml}$ to 25 litres of clean water for 30 minutes) may produce microbiologically safe drinking water high initial microbial load and post-disinfection residual chlorine loss may limit its efficacy.

Keywords: Bacterial resuscitation, Escherichia coli, Dechlorination, Drinking water, Salmonella typhi, WaterCare ${ }^{\circledR}$
\end{abstract}

\section{INTRODUCTION}

Water resource challenges have long existed in the urban, peri-urban and rural settlements of sub-Saharan Africa and several other developing countries. However, the devastating impacts have been amplified in recent times. Coupled with the peculiar challenges of these resource-constraint countries, poor sanitation, which is closely linked to poverty, has emerged as a leading factor responsible for the considerable decline in availability of safe water sources for drinking and other purposes (Freitas, 2013). Diarrhoea and other waterborne infectious diseases of bacterial, viral and parasitic aetiology are leading causes of morbidity and child mortality in these regions, accounting for up to $9 \%$ of total deaths of under-fives in 2015 (UNICEF, 2017). This translates to over 1,400 infant deaths daily, despite the availability of simple preventive interventions such as point-of-use drinking water disinfection (UNICEF, 2017).

Municipal safe water supply in developing countries is known to be ineffective and often unavailable. Small-scale household-based water treatment technologies have been recommended as low-cost alternatives. These include the use of point-of-use chemical disinfectants, solar disinfection (SODIS), boiling and filtration among others (Angulo et al., 1997; Rose et al., 2006; CDC, 2008; Laun, 2015). In recent times hypochlorite-based disinfectants are packaged in form of cheap, easy-to-apply, portable point-of-use disinfectants and marketed under various brand names including WaterGuard ${ }^{\circledR}$ and WaterCare ${ }^{\circledR}$ (USEPA, 2011).

The initial microbiological quality of raw water samples, amidst several other factors (such as $\mathrm{pH}$, temperature and presence of particulate matter) that affect the effectiveness of chemical disinfectants (Nurizzo et al., 2005; Waters and Hung, 2014), is a major factor to consider in the assessment of the efficacy of drinking water disinfectants. High initial microbial load in water samples can exert a hampering effect on the antimicrobial properties of disinfectants by reducing their effective concentrations, thereby lowering the eventual efficacy of the disinfection process. Imperatively, an assessment of the influence of initial bacterial load on the efficacy of point-of-use chlorine-based disinfectant products such as WaterCare ${ }^{\circledR}$ is essential.

Furthermore, the eventuality of post-disinfection residual chlorine loss is usually due to several prevailing physicochemical conditions in water 
storage and distribution systems (LeChevallier et al., 1996; Dvorak, 2005; Laun, 2015).This ultimately results in bacterial resuscitation or regrowth, and highlights a major limitation to both small- and large-scale chlorination efficacy (Igunnugbemi et al., 2004; Li et al., 2013). Storage of chlorinated water in earthen vessels with high organic matter content and the distribution of chlorinated water via corroded or leaky pipes and joints can lead to residual chlorine loss in stored and pipe-borne water systems respectively (Igunnugbemi et al., 2004; Morrow et al., 2008; Owolabi and Azeez, 2010). It is therefore imperative to evaluate the influence of dechlorination on inactivated or chlorine-injured bacteria in drinking water systems treated with branded point-of-use disinfectants.

Hence, the objectives of this present study are: to evaluate the effects of initial bacterial load and dechlorination idiosyncrasy on the efficacy of varying concentrations WaterCare ${ }^{\circledR}$ in drinking water.

\section{MATERIALS AND METHODS}

\section{Preparation of Culture Media}

All growth media used in this study were prepared according to the manufacturer's specifications. The media used include nutrient agar and nutrient broth purchased from Rapid Lab. (Colchester, UK); MacConkey agar (MCA), Salmonella/Shigella agar (SSA), cysteine lactose electrolyte deficient medium (CLED) obtained from Oxoid Chemicals (Reading, UK). The chemical reagents used for phosphate buffer saline (PBS: $8 \mathrm{~g} \mathrm{NaCl}, 0.2 \mathrm{~g} \mathrm{KCl}, 1.44 \mathrm{~g}$ $\mathrm{Na}_{2} \mathrm{HPO}_{4}$, and $0.24 \mathrm{~g} \mathrm{KH} \mathrm{KO}_{4}$ in $1000 \mathrm{ml}$ of distilled water) are of analytical grade and supplied by Fluka Chemie (Buchs, Switzerland).

\section{Cultivation, Harvest and Purification of Isolates}

The isolates Escherichia coli, Salmonella typhi, Shigella dysenteriae and Proteus vulgaris were obtained from the culture collection of the Department of Microbiology, University of Ilorin, Kwara State, Nigeria. The test organisms were resuscitated from their stocks by repeated subculturing on nutrient agar using the streaking method. The identities of the organisms were validated using cultural (characteristic growth on selective-differential media such as MCA, SSA and CLED), biochemical (indole production, methylred, Voges-Proskauer, citrate utilisation, sulfur reduction, urease production, tryptophan deaminase production, sugar fermentation, $\mathrm{H}_{2} \mathrm{~S}$ production, triple sugar iron utilisation, etc) and microscopic (gram reaction, motility, cell shape and cell arrangement) techniques (Fawole and Oso, 2004).

Specimens of each of the organisms (2-3 loopful of distinct colonies) were inoculated into $150 \mathrm{ml}$ of double strength nutrient broth incubated on an orbital shaker incubator $\left(37^{\circ} \mathrm{C}\right.$, $100 \mathrm{rpm})$ for $48-72 \mathrm{~h}$ and observed daily for increase in turbidity. Cells growing at exponential phase were harvested by centrifugation at $3500 \mathrm{rpm}$ for 10 minutes. Pure cell pellets were obtained by re-suspension in PBS and repeated centrifugation. After each centrifugation, the supernatant was carefully decanted and discarded. This procedure was performed separately for the individual organisms. The purified cell pellets were finally maintained in a suspension of PBS and stored in the refrigerator $\left(4^{\circ} \mathrm{C}\right)$ until use, but not more than 4 days.

\section{Standardization of Inoculum Size}

The concentration of bacterial cells in suspension was quantified by measuring the optical density on a spectrophotometer (Genesys 20 model) at a wavelength of $600 \mathrm{~nm}$. McFarland's turbidity standards (1\% anhydrous $\mathrm{BaCl}_{2}$ and $1 \% \mathrm{H}_{2} \mathrm{SO}_{4}$; Smibert and Kreig, 1994) were used to adjust the concentrations of the inoculums. The suspension was adjusted by dilution until its absorbance was within the range of $0.6-0.7$ which is equivalent to $12 \times 10^{8}$ $\mathrm{CFU} / \mathrm{ml}$. This was done just before the experimental setups.

\section{Assaying for Influence of Inoculum Size on Disinfectant Efficacy}

This experiment was carried out using two organisms Escherichia coli and Salmonella typhi. Here, the inoculum size of the cell 
suspension and the dose levels of the WaterCare ${ }^{\circledR}$ were varied. The inoculum sizes used were $10^{2}, 10^{4}$ and $10^{6} \mathrm{CFU} / \mathrm{ml}$; they were achieved by serial dilution of the original cell suspension $\left(12 \times 10^{8} \mathrm{CFU} / \mathrm{ml}\right)$. An aliquot $(1 \mathrm{ml})$ of each of the three different diluted cell suspensions was inoculated into $99 \mathrm{ml}$ of sterile distilled water in a conical flask and mixed thoroughly. From these, $10 \mathrm{ml}$ was transferred aseptically into each sterile test tube and dosed with either 0.72 or $0.108 \%(\mathrm{v} / \mathrm{v})$ WaterCare ${ }^{\circledR}$. The disinfectant was left to react with the bacterial cells for 30 minutes. After this contact time, $1 \mathrm{ml}$ aliquot was drawn from each test tube and serially diluted up to $10^{-4}$ for the $10^{6}$ inoculum size setup, and to $10^{-2}$ for the $10^{4}$ inoculum size setup. The $10^{2}$ inoculum size setup was not diluted. Then $0.5 \mathrm{ml}$ each from these dilutions was inoculated on the appropriate selective-differential media using the standard pour plate technique (APHA, 2002). This represented 30 minutes post-contact time. Following 60 and 150 minutes postcontact times, $1 \mathrm{ml}$ was withdrawn from each experimental test tube and process of dilution, inoculation and incubation repeated. Escherichia coli was inoculated on MCA and incubated at $45^{\circ} \mathrm{C}$ while Salmonella typhi was inoculated on SSA and incubated at $37^{\circ} \mathrm{C}$, respectively. The plates were enumerated after 24 and $48 \mathrm{~h}$ of incubation. The experiment was repeated twice and the mean values of readings recorded.

\section{Assaying for Influence of Dechlorination on Bacterial Resuscitation}

This assay was done to evaluate the influence of dechlorination on the efficacy of hypochlorite in water disinfection. Four organisms Escherichia coli, Salmonella typhi, Shigella dysenteriae and Proteus vulgaris with only one inoculum size $\left(10^{6}\right.$ cells $\left./ \mathrm{ml}\right)$ and seven hypochlorite concentrations $(0.018,0.036$, $0.054,0.072,0.090,0.108$, and $0.126 \% \mathrm{v} / \mathrm{v}$ ) were used in this experiment. The set up followed method earlier described above. The disinfectant was left to react with the bacterial cells in the flasks for 30 minutes and then $1 \mathrm{ml}$ of $1 \%$ sodium thiosulphate was added to the hypochlorite-treated water samples to dechlorinate. Thereafter, $1 \mathrm{ml}$ was drawn from each test tube and serially diluted up to $10^{-4}$ dilution. An aliquot of this final dilution $(0.5 \mathrm{ml})$ was then inoculated on the appropriate selective-differential media and the plates incubated as described above. This represented 0 minute post-dechlorination. The process of dilution, inoculation and incubation was repeated after 10, 30, 120, 360 and 1440 minutes post-dechlorination. Escherichia coli was inoculated on MCA and incubated at $45^{\circ} \mathrm{C}$. Salmonella typhi and Shigella dysenteriae were inoculated on SSA, while Proteus vulgaris was inoculated on CLED, all of which were incubated at $37^{\circ} \mathrm{C}$. Triplicate plate counts were conducted for each setup.

\section{Statistical Analysis}

The mean values of triplicate readings of bacterial counts were determined using MS Excel version 2013. Graphs of time-course resuscitation of the bacterial cells were drawn with SigmaPlot version 14 (IBM SPSS, IL, USA). Effects of initial microbial load and concentration of disinfectant on bacterial numbers were analysed using SigmaStat statistical software version 3.5 (IBM SPSS, IL, USA) and significance reported at $p<0.05$.

\section{RESULTS AND DISCUSSION}

The results of influence of inoculum size on disinfectant efficacy are shown in Tables 1 and 2. After the first 24 hours of incubation, there was a complete inactivation of both Escherichia coli and Salmonella typhi at both hypochlorite concentrations and for all exposure times irrespective of the initial bacterial loads (Tables 1 and 2). However, appreciable growths were observed upon further incubation of the culture plates for an additional $24 \mathrm{~h}$. This suggests that the bacterial cells were mainly stressed and injured, as many factors including the physiological history of cells, specific physicochemical conditions of growth medium and chemical stresses such as chlorination can lead to the extension of the lag or adjustment phase of cultured bacteria (Davis et al., 2005; Rolfe et al., 2012; Stratford et al., 2014). 
Table 1: Influence of inoculum size on the efficacy of hypochlorite against Escherichia coli

\begin{tabular}{|c|c|c|c|c|c|c|c|}
\hline \multirow{5}{*}{$\begin{array}{l}\text { Hypochlorite concentration } \\
(\% \mathrm{v} / \mathrm{v})\end{array}$} & \multirow{5}{*}{$\begin{array}{l}\text { Initial inoculum size } \\
\text { (CFU/ml) }\end{array}$} & \multicolumn{6}{|c|}{ Bacterial Number (CFU/ml) } \\
\hline & & \multicolumn{6}{|c|}{ Incubation time (h) } \\
\hline & & \multicolumn{3}{|c|}{24} & \multicolumn{3}{|c|}{48} \\
\hline & & \multicolumn{6}{|c|}{ Post-contact time (minutes) } \\
\hline & & 30 & 60 & 150 & 30 & 60 & 150 \\
\hline \multirow{3}{*}{0.072} & $1 \times 10^{2}$ & 0 & 0 & 0 & 11 & 3 & 2 \\
\hline & $1 \times 10^{4}$ & 0 & 0 & 0 & 40 & 13 & 23 \\
\hline & $1 \times 10^{6}$ & 0 & 0 & 0 & 130 & 120 & 80 \\
\hline \multirow{3}{*}{0.108} & $1 \times 10^{2}$ & 0 & 0 & 0 & 7 & 0 & 0 \\
\hline & $1 \times 10^{4}$ & 0 & 0 & 0 & 20 & 4 & 4 \\
\hline & $1 \times 10^{6}$ & 0 & 0 & 0 & 70 & 40 & 30 \\
\hline
\end{tabular}

Table 2: Influence of inoculum size on the efficacy of hypochlorite against Salmonella typhi

\begin{tabular}{|c|c|c|c|c|c|c|c|}
\hline \multirow{5}{*}{$\begin{array}{l}\text { Hypochlorite concentration } \\
(\% \mathrm{v} / \mathrm{v})\end{array}$} & \multirow{5}{*}{$\begin{array}{l}\text { Initial inoculum size } \\
\text { (CFU/ml) }\end{array}$} & \multicolumn{6}{|c|}{ Bacterial Number (CFU/ml) } \\
\hline & & \multicolumn{6}{|c|}{ Incubation time (h) } \\
\hline & & \multicolumn{3}{|c|}{24} & \multicolumn{3}{|c|}{48} \\
\hline & & \multicolumn{6}{|c|}{ Post-contact time (minutes) } \\
\hline & & 30 & 60 & 150 & 30 & 60 & 150 \\
\hline \multirow{3}{*}{0.072} & $1 \times 10^{2}$ & 0 & 0 & 0 & 5 & 0 & 0 \\
\hline & $1 \times 10^{4}$ & 0 & 0 & 0 & 18 & 0 & 0 \\
\hline & $1 \times 10^{6}$ & 0 & 0 & 0 & 150 & 0 & 0 \\
\hline \multirow{3}{*}{0.108} & $1 \times 10^{2}$ & 0 & 0 & 0 & 1 & 0 & 0 \\
\hline & $1 \times 10^{4}$ & 0 & 0 & 0 & 12 & 0 & 0 \\
\hline & $1 \times 10^{6}$ & 0 & 0 & 0 & 110 & 0 & 0 \\
\hline
\end{tabular}

Stressed bacterial cells were recovered on the 48-h culture plates, with the counts decreasing with increasing exposure time and disinfectant concentration. Especially for Escherichia coli, the highest inactivation levels were recorded at the highest exposure time (150 minutes) and higher hypochlorite concentration $(0.108 \% \mathrm{v} / \mathrm{v})$. These results indicate that, bacterial survival in the treated water is dependent on the initial bacterial load as well as on the hypochlorite concentration applied and contact time allowed for disinfection (Tables 1 and 2). It is also noteworthy that the acute pathogen, Salmonella typhi, was more susceptible to hypochlorite disinfection (Table 2) than the indicator organism, Escherichia coli (Table 1) as there was complete inactivation of the pathogen after 60 and 150 minutes post-exposures to both hypochlorite concentrations.
The results of the influence of dechlorination idiosyncrasy on hypochlorite efficacy are presented in Figure $1(a-d)$. Prior hypochlorite disinfection (applied at $0.018-0.126 \% \mathrm{v} / \mathrm{v}$ ) caused significant cell reductions in all four test organisms: over 6-fold in Salmonella typhi (Figure 1b); over 5-fold in Shigella dysenteriae (Figure 1c); and over 4-fold in Escherichia coli and Proteus vulgaris (Figure $1 \mathrm{a}$ and $\mathrm{d}$ ). However, significant bacterial resuscitation following dechlorination of the treated water was observed at all hypochlorite concentrations. For Escherichia coli, low cell numbers were maintained within the first 30 minutes post-dechlorination at all hypochlorite concentrations. 


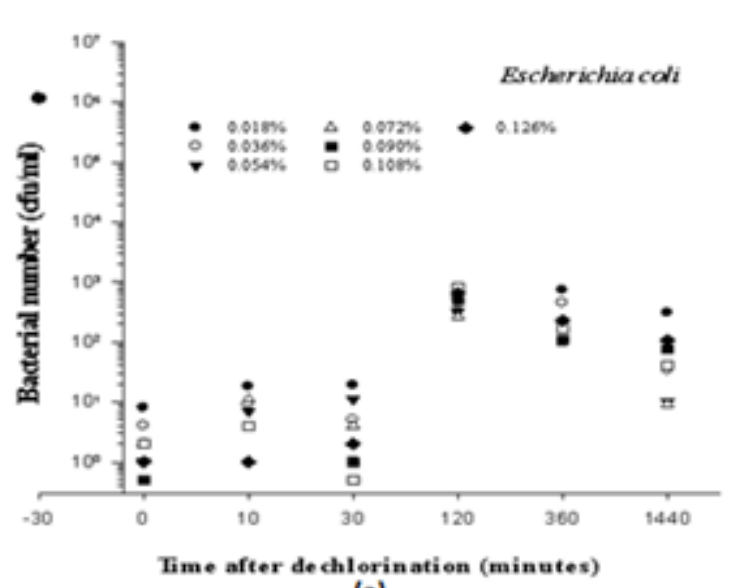

(a)

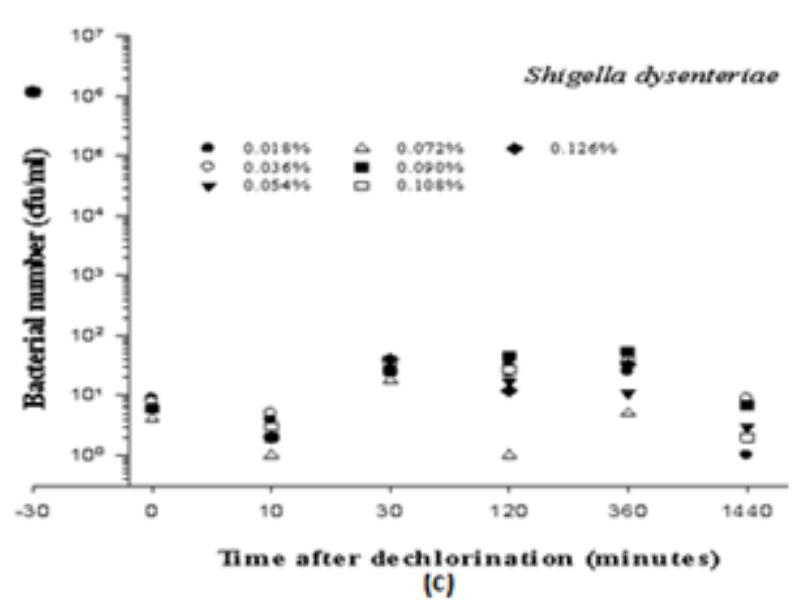

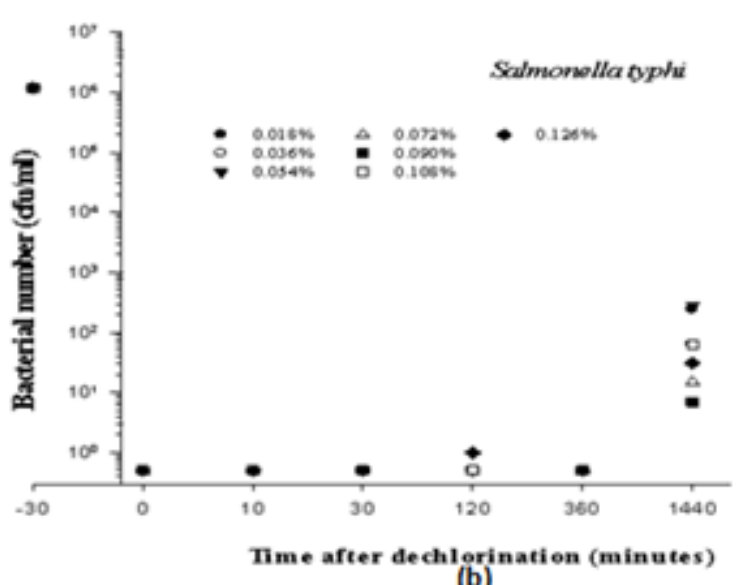

(b)

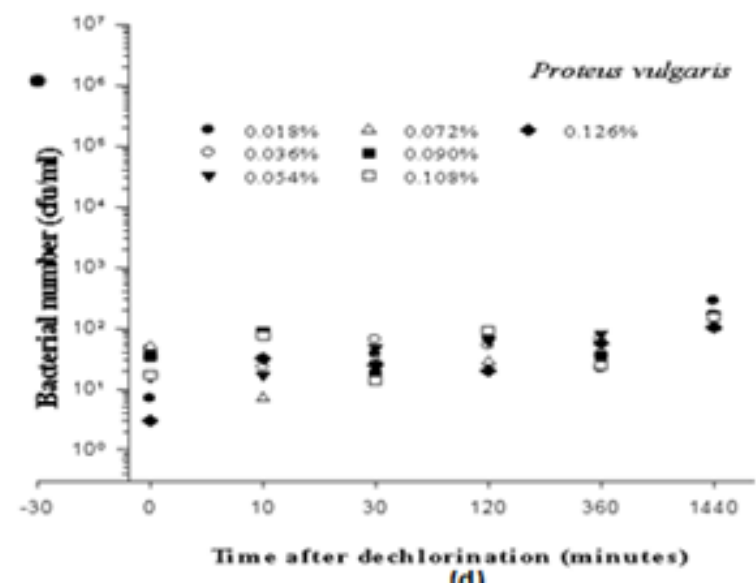

(d)

Figure 1: Resuscitation of (a) Escherichia coli, (b) Salmonella typhi,(c) Shigella dysenteriae and (d) Proteus vulgaris after dechlorination of hypochlorite-treated water

However, there was an apparent resurgence (by about 2-fold) in cell numbers between 120 and 360 minutes, and then a mild decline at 1440 minutes post-dechlorination (Figure 1a). Consistent with the high susceptibility of Salmonella typhi to the proprietary disinfectant, the organism showed very low levels of recovery until about 1440 minutes postdechlorination when moderate resuscitation of cells was observed (Figure 1b). Shigella dysenteriae also demonstrated significant postdechlorination resuscitation after 30-360 minutes particularly at the lower hypochlorite concentrations (0.018-0.054 \% v/v) (Figure 1c). Similarly and more apparently, resuscitation of Proteus vulgaris cells maintained a consistent rise between 10 and 1440 minutes postdechlorination (Figure 1d).

The results of this study therefore highlight the eventuality of bacterial resuscitation following residual chlorine loss in treated water. Bacteria regrowth in chlorinated water is a phenomenon that has been reported in several other studies (LeChevallier et al., 1996; Igunnugbemi et al., 2004; Rizzo et al., 2004; Owolabi and Azeez, 2010; Li et al., 2013; Archarya et al., 2016). Hence, the eventuality of its occurrence hints on a major limitation to the use of WaterCare ${ }^{\circledR}$. There is need to also evaluate the efficacy of other chlorine-based disinfectants. It has been reported that chlorine-injured enteric pathogens retain their potential for enterotoxigenicity and are able to recover in the small intestines of animals when ingested (Bitton, 2005). Therefore, factors leading to dechlorination remain important public health risk, especially in sub-Saharan Africa where elevated ambient temperatures can further encourage bacteria proliferation after they are resuscitated. These risk factors include prolonged water storage and other physicochemical conditions in 
chlorinated water storage and distribution systems such as the use of earthen vessels and improperly conditioned pipes (Bitton, 2005; Morrow et al, 2008; Owolabi and Azeez, 2010).

\section{CONCLUSION}

Although the branded chlorine-based product (WaterCare ${ }^{\circledR}$ ) used in this study substantially inactivated the pathogens (even at concentrations lower than the manufacturer's recommended dosage of $0.4 \mu \mathrm{l} \mathrm{ml-1}$ or $10 \mathrm{ml}$ to 25 litres of clean water for 30 minutes), dechlorination of treated water revealed that the inactivated cells may be resuscitated. Thus, whilst the use of WaterCare ${ }^{\circledR}$ at the recommended dosage may produce microbiologically safe water high microbial load and post-disinfection residual chlorine loss may limit its efficacy.

\section{ACKNOWLEDGEMENT}

The authors appreciate S. O. Olabanji, Chief Technologist, Department of Microbiology, University of llorin for the provision of the isolates.

\section{Conflicts of Interest}

All authors declare no conflict of interest.

\section{REFERENCES}

Angulo, F. J., Tippen, S., Sharp, D. J., Payne, B. J., Collier, C., Hill, J. E., Barrett, T. J, Clark, R. M., Geldreich, E. E., Donnell, H. D. and Swerdlow, D. L. (1997). A community waterborne outbreak of salmonellosis and the effectiveness of a boil water order. American Journal of Public Health, 87(4): 580-584.

Archarya, S. M., Kurisu, F., Kasuga, I. and Furumai, H. (2016). Chlorine dose determines bacteria community structure of subsequent regrowth in reclaimed water. Journal of Water and Environment Technology, 14(1): 15-24.

American Public Health Association (APHA) (2002). Standard Methods for the Examination of Water and Waste water. $20^{\text {th }}$ ed. American Public Health Association, Washington D.C., USA
Bitton, G. (2005). Microbiology of drinking water treatment. In: Wastewater Microbiology; $3^{\text {rd }}$ edition, John Wiley and Sons Inc., New York. pp. 183, 395455. ISBN 0-471-65071-4.

Centres for Disease Control and Prevention (CDC) (2008). Household water treatment options in developing countries: household chlorination. Retrieved March10, 2020, from https://www.cdc.gov/safewater/chlorination. $\underline{\mathrm{html}}$

Davis, K. E. R., Joseph, S. J. and Janssen, P. $H$. (2005). Effects of growth medium, inoculum size and incubation time on culturability of soil bacteria. Applied and Environmental Microbiology, 71(2): 826-834.

Dvorak, G. (2005). Disinfection 101. Centre for Food Security and Public Health lowa State University Publication. http://www.cfsph.iastate.edu/Disinfection/ Retrieved March 10, 2020,

Fawole, M. O., and Oso, B. A. (2004). Laboratory Manual of Microbiology, Spectrum Books Limited, Ibadan, pp. 46.

Freitas, A. (2013). Water as a stress factor in sub-Saharan Africa. European Union Institute for Security Studies: Brief Issue, 12: 1-4. ISSN 2315-1110.

Igunnugbemi, O. O., Eniola, K. I. T., Olayemi, A. B., Awe, S. and Olowe, A. O. (2004). Regrowth of bacteria in chlorinated piped water. Nigerian Journal of Pure and applied Sciences, 19: 1597-1601.

Laun, D. (2015). What are the pros and cons of each of the three forms of chlorine (chlorine gas, sodium hypochlorite, calcium hypochlorite) used for drinking water? Occurence Assessments for the Final Stage 2 Disinfectants and Disinfection Byproducts Rule, EPA815R-05-011. Retrieved March 10, 2020,from https://safewater.zendesk.com/hc/enus/articles/212078887.

LeChevallier, M. W., Welch, N. J. and Smith, D. B. (1996). Full-scale studies of factors related to coliform regrowth in drinking 
water. Applied \& Environmental Microbiology, 62(7): 2201-2211.

Li, D., Zeng, S., Gu, A.Z. and Shi, H. (2013). Inactivation, reactivation and regrowth of indigenous bacteria in reclaimed water after chlorine disinfection of a municipal wastewater treatment plant. Journal of Environmental Sciences, 25(7): 1319-1325.

Morrow, J. B., Almeida, J. L., Fitzgerald, L. A. and Cole, K. D. (2008). Association and decontamination of Bacillus spores in a simulated drinking water system. Water Research, 42: 5011-5021.

Nurizzo, C., Antonelli, M., Profaizer, M. and Romele, L. (2005). By-products in surface and reclaimed water disinfected with various agents. Desalination, 176: 241-253.

Owolabi, R. U. and Azeez, L. A. (2010). Transit monitoring of residual chlorine in AweOyo area of Nigeria water township supply. International Journal of Chemical Engineering and Applications, 1(2): 143-146.

Rizzo, L., Belgiorno, V. and Napoli, R. M. A. (2004). Regrowth evaluation of coliform bacteria injured by low chlorine doses using selective and non-selective media. Journal of Environmental Science and Health, 39(8): 2081-2092.

Rolfe, M. D., Rice, C. J., Lucchini, S., Pin, C., Thompson, A., Cameron, A. D. S., Alston, M., Stringer, M. F., Betts, R. P., Baranyi, J., Peck, M. W. and Hinton, J. C. D. (2012). Lag phase is a distinct growth phase that prepares bacteria for exponential growth and involves transient metal accumulation. Journal of Bacteriology, 194(3): 686-701.
Rose, A., Roy, S., Abraham, V., Holmgren, G., George, K., Balraj, V., Abraham, S., Muliyil, J., Joseph, A. and Kang, G. (2006). Solar disinfection of water for diarrhoeal prevention in southern India. Archives of Disease in Childhood, 91: 139-141.

Smibert, R. M. and Kreig, N. R. (1994). Phenotypic characterization, In: Gerhardt, P. et al. (eds). Method for General and Molecular Bacteriology. American Society for Microbiology, Washington, DC. pp. 607-654.

Stratford, M., Steels, H., Nebe-von-Caron, G., Avery, S. V., Novodvorska, M. and Archer, D. B. (2014). Population heterogeneity and dynamics in starter culture and lag phase adaptation of the spoilage yeast Zygosaccharomyces bailii to weak acid preservatives. International Journal of Food Microbiology, 180: 40-47.

UNICEF (2017). Diarrhoea remains a leading killer of young children, despite the availability of a simple treatment solution. UNICEF data: monitoring the situation of women and children. Retrieved March 20, 2017, from https://www.unicef.org.

United States Environmental Protection Agency (USEPA) (2011). Chlorination and chloramination. In: Water Treatment Manual: Disinfection. ISBN: 978184095-421-0. pp. 3, 51-55.

Waters, B. W. and Hung, Y. C. (2014). The effect of organic loads on stability of various chlorine-based sanitizers. International Journal of Food Science and Technology, 49: 867-875. 